UDC 573.3:577.29:616.8-092

\title{
MODELING OF MOLECULAR PROCESSES UNDERLYING PARKINSON'S DISEASE IN CELLS OF METHYLOTROPHIC YEAST HANSENULA POLYMORPHA
}

\author{
I. O. Denega ${ }^{1,2}$, N. I. Klymyshyn ${ }^{2}$, N. O. Sybirna ${ }^{2}$, O. V. Stasyk ${ }^{1}$, O. G. Stasyk ${ }^{1,2}$ \\ 1 Institute of Cell Biology of NAS of Ukraine, 14-16, Drahomanov St., Lviv 79005, Ukraine \\ 2Ivan Franko National University of Lviv, 4, Hrushevskyi St., Lviv 79005, Ukraine \\ e-mail: olenastasyk@gmail.com
}

\begin{abstract}
Abnormal oligomerisation and aggregation of the protein called alpha-synuclein ( $\alpha$-syn) are the key events in the pathogenesis of Parkinson's disease (PD). Recent discoveries revealed cellular pathways that potentially relate neurodegenerative disease (ND) to abnormal functioning of mitochondria or anomalous glucose metabolism. In this study we describe for the first time strains of the thermotolerant methylotrophic yeast Hansenula polymorpha that produce human GFP-tagged $\alpha$-syn as a new model of molecular processes leading to PD. We observed that NCYC495-SNCA wild-type strain did not form visible $\alpha$-syn amyloid-like aggregates but exhibited plasma membrane perforations and cytoplasm leakage. gcr1-2-SNCA mutant strain deficient in catabolite repression and glucose transport exhibited enhanced aggregation of fluorescently tagged $\alpha$-syn. However, the observed differences did not result from the impaired glucose metabolism as were observed in both $\alpha$-syn-producing strains grown on glycerol. Production of $\alpha$-syn was detrimental for both strains and decreased their growth rate on alternative carbon sources. Our data suggests that $H$. polymorpha may serve as an informative new yeast model for deciphering molecular mechanisms of PD that regulate amyloid formation and degradation under the influence of various extra- and intracellular factors.
\end{abstract}

Keywords: methylotrophic yeast, $\alpha$-synuclein, amyloids, neurodegeneration.

\section{INTRODUCTION}

Human neurodegenerative diseases such as Alzheimer's disease, Parkinson's disease, dementia with Lewy bodies, and Huntington's disease belong to the superfamily of pathologies known as protein misfolding disorders [27]. It is now known that these disorders have some common cellular and molecular mechanisms including protein misfolding and aggregation and formation of inclusion bodies. These aggregates usually consist of fibers containing misfolded proteins with $\beta$-sheet conformation, termed amyloid [21]. The composition of the aggregates, as well as their localization in organs and tissues, is specific for each disease. For example, in PD there is abnormal accumulation of synuclein in neuronal cell bodies, axons, and synapses [11]. This disease represents

ISSN 1996-4536 (print) • ISSN 2311-0783 (on-line) • Біологічні Студії / Studia Biologica • 2014 • Том 8/№2 • C. 5-16 
a group called synucleinopathies. Pathological brain inclusions composed of filamentous, mainly insoluble $\alpha$-syn protein that affect substantia nigra are called Lewy bodies (LB).

Human $\alpha$-syn is a small heat-stable cytoplasmic protein of 140 amino acids found primarily at presynaptic terminals of the central nervous system (CNS) [17, 29]. Although the exact role of $\alpha$-syn in normal cell functioning remains to be fully defined, $\alpha$-syn is assumed to be involved in the regulation of synaptic-vesicle release and trafficking, fatty acid-binding and stabilising complexes of SNARE family proteins, therefore affecting membrane stability and neuronal plasticity and survival [29, 31]. Ample evidence suggests that overproduction of $\alpha$-syn interrupts normal cell functions resulting in decreased neurite outgrowth and cell adhesion [7].

Abnormal interactions and misfolding of synaptic proteins in the nervous system are being extensively explored as important pathogenic events resulting in neurodegeneration in various neurological disorders. A natively unfolded protein, $\alpha$-syn, can adopt different conformational states and different aggregated morphologies, including small aggregates, oligomers, spherical and linear protofibrils, and fibrils [31]. At present it is widely accepted that abnormal oligomerisation and aggregation of $\alpha$-syn are the key events in PD pathogenesis $[5,6]$. There is ongoing intense debate regarding the nature of the aggregates and protein forms that are toxic in neurodegenerative disorders. Some studies suggest that earlier aggregation intermediates, such as oligomers, are more toxic than larger inclusions and that the smaller nonfibrillar species of $\alpha$-syn are the ones that may primarily exert the neurotoxic effect [6]. The formation of such oligomers in vitro led to the increase in leakiness of synthetic lipid vesicles [30]. Direct in vivo data supporting the "toxic oligomeric $\alpha$-syn hypothesis" are still relatively limited and most of the evidence is circumstantial. The conclusion about the role of large insoluble $\alpha$-syn aggregates, the hallmark of PD, inside or outside cells has also been switching between the toxic and cytoprotective properties during the last decade. However, it has been recently demonstrated that $\alpha$-syn fibrillar assemblies exhibit a level of cytotoxicity at least 1,000-fold higher than that of their precursor oligomers at identical particles concentrations, the toxicity being associated with their ability to bind and permeabilize the cell membranes [20].

Despite the fact that a primary cause for PD is yet to be identified, a number of risk factors are known. Although there is the occasional case of the disease being developed in a young adult, it generally manifests itself in the middle to late years of life and the risk continues to increase with age. Various trigger factors, either genetic such as point mutations in $\alpha$-syn SNCA gene or environmental, such as low $\mathrm{pH}$, high temperature, metal cations, pesticides, heparin and other glycoseaminoglycans have also been shown to play a role in conversion of $\alpha$-syn into its $\beta$-sheet conformation [7]. Several recent discoveries have highlightened common cellular pathways that potentially relate neurodegenerative processes with abnormal functions of mitochondria and anomalous glucose metabolism [23, 26, 32]. It has been reported that diabetes mellitus type II is associated with increased PD risk [26, 32]. PD has also been associated with reduced insulin-mediated glucose uptake, inhibition of early insulin secretion and long-term hyperinsulinaemia and hyperglycaemia after glucose loading [1].

Intense research has also been conducted to generate artificial models that closely resemble PD, including animal and yeast models [9]. Importantly, yeast and human cells share basic fundamental aspects of eukaryotic cell biology. This allows a number of key processes, which are of particular interest to PD pathology, to be efficiently investigated in the well-understood yeast model. These include the mechanisms of protein folding,

ISSN 1996-4536 (print) • ISSN 2311-0783 (on-line) • Біологічні Студії / Studia Biologica • 2014 • Том 8/№2 • C. 5-16 
quality control and degradation, the components involved in the secretory pathway and vesicular trafficking, the study of mitochondrial dysfunction and oxidative stress, the mechanisms of cell death and survival [9].

Bakers' yeast Saccharomyces cerevisiae has traditionally been the most popular model yeast for PD studies [18, 27]. However, it is now recognized that its physiology and genetic apparatus, for instance involved in glucose consumption, are highly specialized to support fermentative growth [24]. Here we attempted to evaluate methylotrophic yeast Hansenula polymorpha as an alternative yeast model for investigation of molecular mechanisms of PD. The full genome for this yeast is publicly available, regulated heterologous gene expression systems are well developed and mutants deficient in glucose transport were described for $H$. polymorpha $[10,13]$. Crucially, it is the thermotolerant yeast, contrary to S. cerevisiae, capable of growth at $37{ }^{\circ} \mathrm{C}$ which is a physiological temperature for human organism.

In this study we addressed the question whether $\alpha$-syn expression in $H$. polymorpha host impaired in glucose transport and metabolism would be more toxic relative to the wild type strain. For this, we utilized previously described by us $H$. polymorpha strain harboring mutation in the GCR1 gene, encoding for putative glucose sensor/transporter protein [25].

\section{MATERIALS AND METHODS}

Strains. Used in this study are listed in Table 1.

Table 1. Strains of yeast and bacteria used in this study

Таблиця 1. Штами дріжджів і бактерій, які використовувались у даному дослідженні

\begin{tabular}{|c|c|c|}
\hline Strain & Genotype & Reference \\
\hline \multicolumn{2}{|r|}{ Hansenula polymorpha } & \\
\hline NCYC 495 ura 3 & ura 3 & \\
\hline gcr 1-2 ura 3 & gcr 1-2 ura 3 & [25] \\
\hline NCYC 495 SNCA & leu1-1 ScLUE2 $P_{M E T 25}-y E G F P 3-S N C A-T_{C Y C 1}$ & This work \\
\hline gcr 1-2 SNCA & gcr 1-2 leu1-1 ScLUE2 $P_{M E T 25}-y E G F P 3-S N C A-T_{C Y C 1}$ & This work \\
\hline \multicolumn{2}{|r|}{ Escherichia coli } & \\
\hline$D H 5 \alpha$ & $\begin{array}{l}\text { lacZ } \Delta \mathrm{M} 15, \text { recA1, endA1, gyrA96, thi-1, hsdR17 }\left(\mathrm{r}_{\mathrm{K}}^{-}, \mathrm{m}_{\mathrm{K}}{ }^{+}\right) \text {, } \\
\text { supE44, relA1, deoR, } \Delta(\text { lacZYA-argF }) \mathrm{U} 169\end{array}$ & \\
\hline
\end{tabular}

Media and growth conditions. Yeast strains were cultivated at $37^{\circ} \mathrm{C}$ in rich medium YPS (1\% yeast extract, $2 \%$ bactopeptone, $1 \%$ sucrose) and synthetic minimal medium (SMD) which contained $0.17 \%$ yeast nitrogen base without amino acids and ammonium sulfate (YNB), $1 \%$ glucose or $1 \%$ glycerol, $0.5 \%$ ammonium sulfate, and $40-50 \mathrm{mg} / \mathrm{L}$ of auxotrophic amino acids if needed. Solid media contained agar in $2 \%$ concentration.

Biomass (in optical density units, $\mathrm{OD}_{600}$ ) was estimated via optical absorption (at the wavelength of $600 \mathrm{~nm}$ in $1 \mathrm{~cm}$ cuvette) of diluted suspensions using spectrophotometer "Helios- $\gamma$ ".

DNA procedures. Standard DNA techniques were carried out essentially accordingly to previously described [22]. Transformation of $H$. polymorpha was performed by electroporation [8]. Plasmids used in this study are listed in Table 2. Primers used in this study are listed in Table 3.

ISSN 1996-4536 (print) • ISSN 2311-0783 (on-line) • Біологічні Студії / Studia Biologica • 2014 • Том 8/№2 • С. 5-16 
Table 2. Plasmids and constructed in used this study

Таблиця 2. Вектори, які використовувались у даному дослідженні

\begin{tabular}{|c|c|c|}
\hline Plasmid & Genotype & Reference \\
\hline pKF48 & AmpR CEN ScURA3 $\mathrm{P}_{\text {MET25}}$-GFP- 6xHis-T ${ }_{C Y C 1}$ & [4] \\
\hline pKF48-SNCA 1 & $\begin{array}{l}\text { AmpR CEN ScURA3 } \mathrm{P}_{M E T 25} \text {-GFP- } \\
\text { SNCA(U251MG)-6xHis-T } \\
\text { CYC1 }\end{array}$ & This work \\
\hline pKF48-SNCA 2 & $\begin{array}{c}\text { AmpR CEN ScURA3 } \mathrm{P}_{\text {MET25 }} \text { GFP- SNCA } \\
\text { (HEK293)-6xHis-T CYC1 }\end{array}$ & This work \\
\hline
\end{tabular}

Table 3. PCR primers utilized for amplification of SNCA ORF

Таблиця 3. Праймери, використані для ампліфікації відкритої рамки зчитування гена SNCA методом ПЛР

\begin{tabular}{l|l}
\hline \multicolumn{1}{c|}{ Primer name } & \multicolumn{1}{c}{ Sequence } \\
\hline OG21s & 5'-GCGATCGATATGGATGTATTCATGAAAGGAC-3' \\
\hline OG22 & 5'-GTACTCGAGTTAGGCTTCAGGTTCGTAGTCT-3' \\
\hline
\end{tabular}

Fluorescent microscopy. For fluorescent microscopy yeast cells were synchronized in YPS medium. Then cells were washed three times with sterile distilled water and transferred into SMD with different carbon sources with or without methionine (100 mg/L) for regulation of MET25 promoter with $\mathrm{OD}_{600}=0.1$ to induce GFP-SNCA expression. At 4, 24, 32 and $48 \mathrm{~h}$ cells were collected by centrifugation and placed on ice until observation. Images were captured on fluorescence microscope (Axio Imager A1; Carl Zeiss Microlmaging, Jena, Germany) coupled to a monochrome digital camera (Axio Cam MRm; Carl Zeiss Microlmaging) and processed using the AxioVision 4.5 (Carl Zeiss Microlmaging) and Adobe Photoshop CS5 software (Adobe Systems, Mountain View, CA).

\section{RESULTS AND DISCUSSION}

Construction of vectors for regulated expression of human SNCA ORF in yeast cells. According to the published data $[2,15] \alpha$-syn overproduction is observed in human embryonal kidney, glioblastoma, neuroblastoma and some other tissues. Therefore, we used cDNA from human glioblastoma (U251MG) and from human embryonal kidney (HEK293) to amplify SNCA gene (encoding $\alpha$-syn) using standard PCR method with primers for SNCA ORF. Primers OG21s/OG22 (see Table 3) were flanked with restriction sites for $\mathrm{Clal}$ and $\mathrm{Xhol}$, respectively. The obtained fragments had different sizes: SNCA cDNA from U251MG was approximately $0.3 \mathrm{~kb}$ lenghth and SNCA cDNA from HEK293 was approximately $0.4 \mathrm{~kb}$ (Fig. 1). This difference could be explained by alternative splicing of SNCA transcript, which results in formation of two differently sized mRNAs of 339 and 420 bps in length. It is known that at least three isoforms of $\alpha$-syn are produced via alternative splicing [3]. The major form of the protein, and the one most investigated, is the 140 aminoacids-long transcript. Other isoforms are $\alpha$-syn-126, where exon 3 is lost and lacks residues 41-54; and $\alpha$-syn-112 [28] which lacks residue 103-130 due to the loss of exon 5 [3].

The PCR products harboring the SNCA transcripts and the initial plasmid pKF48 [4] were digested with restriction endonucleases $\mathrm{Xhol}$ and $\mathrm{Clal}$ for subcloning of the human SNCA under control of methionine-regulated yeast $\mathrm{P}_{M E T 25}$ promoter. As a result, the SNCA fragments were fused in-frame to the ORF encoding green fluorescent protein ( $y E G F P 3$ ), 
producing $\mathrm{N}$-terminally GFP-tagged $\alpha$-syn as a final translation product (Fig. 2). $\mathrm{P}_{\text {MET25 }}$ promoter is repressed by supplementation of exogenous methionine to the growth medium and, correspondingly, the maximum expression level can be achieved in medium lacking methionine.

Fig. 1. PCR products obtained after amplification with a pair of primers $0 \mathrm{G} 21 \mathrm{~s} / \mathrm{OG} 22$ from templates: 1 - U251MG cDNA (human glyoblastome); 2 HEK293 cDNA (human embryonal kidney)

Рис. 1. Продукти ПЛР, ампліфіковані з використанням пари праймерів OG21s/OG22 та ДНК-матриці: 1 - кДНК U251MG (людської гліобластоми); 2 кДНК НЕК293 (ембріональної нирки людини)

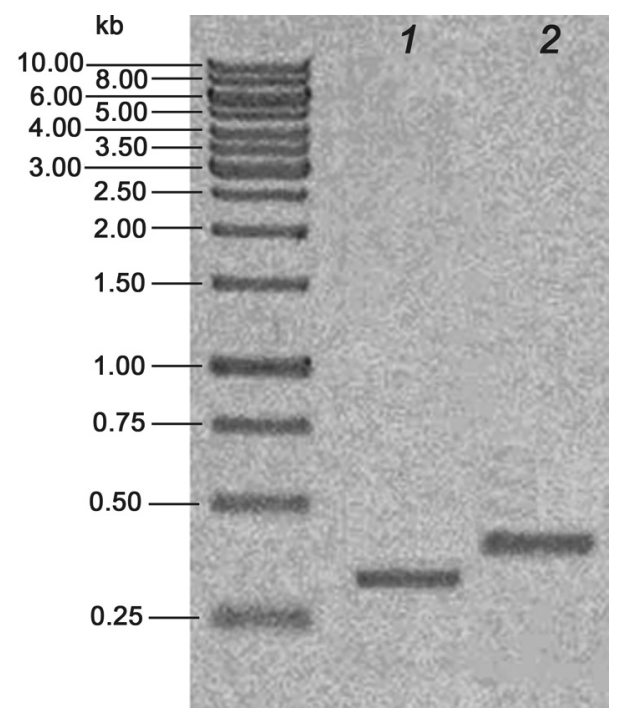

The obtained plasmids were verified for the presence of SNCA transcripts placed under MET25 (0,34 kb or 0,42 kb lenghth) by PCR using primers OG21s and OG22 (Table 3). Based on the PCR analysis, we obtained pKF48-SNCA1 vector containing short SNCA form from glioblastoma and pKF48-SNCA2 with long SNCA form from human embryonal kidney. The scheme of pKF48-SNCA2 (hereinafter referred to as pKF48-SNCA) that harbors full length SNCA from HEK293, which was selected for further analysis, is shown in Fig. 2.

Isolation of $\boldsymbol{H}$. polymorpha starins producing human $\alpha$-syn. The constructed vector pKF48-SNCA was linearized with Stul and transformed into $H$. polymorpha NCYC495 ura3 and gcr1-2 ura3 uracil auxotrophic strains. The transformants were selected on plates with synthetic minimal medium based on the restored prototrophy due to the presence of yeast URA3 selectable marker on the initial vector pKF48.

We performed fluorescent microscopy analysis of $y E G F P 3-S N C A$ expression in the isolated prototrophic strains incubated for 4 hours in minimal medium lacking methionine conferring maximal induction of MET25 promoter versus methionine-supplemented medium. We observed green fluorescence in transformant strains cultured in the methioninedevoid medium, contrary to diminished fluorescence in methionine-supplemented medium or no fluorescence in parental strain that served as a negative control (data not shown).

$\alpha$-syn production affects growth of the yeast model strains on different carbon sources. We analyzed whether $\alpha$-syn gene expression affects growth of the obtained $H$. polymorpha recombinant strains on alternative carbon sources. We observed that, indeed, grown on glucose or glycerol as carbon sources, the wild-type NCYC495SNCA and glucose transport-impaired gcr1-2-SNCA strain both exhibited growth impairment relative to initial strains NCYC495 and gcr1-2 and strains expressing GFP gene only under $\mathrm{P}_{\text {MET25 }}$ promotor (Fig. 3).

ISSN 1996-4536 (print) • ISSN 2311-0783 (on-line) • Біологічні Студії / Studia Biologica • 2014 • Том 8/№2 • C. 5-16 


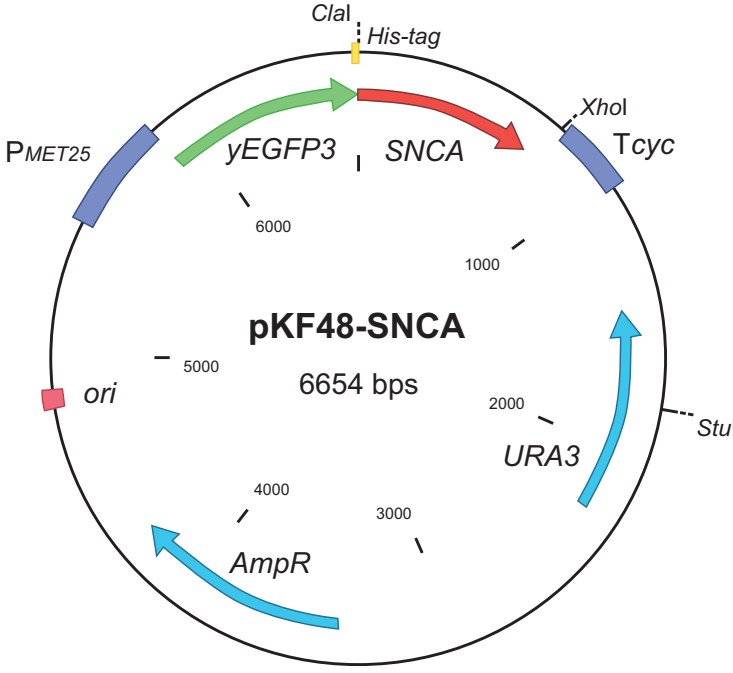

Fig. 2. Plasmid pKF48-SNCA (AmpR CEN URA3 PMET25-GFP-6xHis-TCYC1). Physical map of vector: arrows indicate locations and orientations of the ORFs. The vector contains the URA3 selectable marker, and gene of ampiciline resistance $(A m p R)$ for selection of the $E$. coli transformants. It also contains 6xHis-tag encoding region, allowing to detect fused protein by Western blot analysis using the corresponding primary antibodies. pKF48 bears a yEGFP3 (yeast-enhanced Green Fluorescent Protein) coding sequence under the control of the MET25 promoter which is positively regulated in medium lacking methionine. Human SNCA gene has been cloned into pKF48-SNCA using restriction enzymes Xhol, Clal (marked on the map) so that the GFP is fused to $\mathrm{N}$-terminal end of $\alpha$-syn protein

Рис. 2. Плазміда pKF48-SNCA (AmpR CEN URA3 PMET25-GFP-6xHis-TCYC1). Фізична карта вектора: стрілкою позначено локалізацію та орієнтацію відкритих рамок зчитування. Вектор містить селективний маркер URA3 і ген резистентності до ампіциліну $(A m p R)$ для селекції трансформантів E. coli. Цей вектор також мітить $6 x$ His-tag кодуючу ділянку, яка дає змогу детектувати химерний білок методом Вестерн блот-аналізу за допомогою відповідних первинних антитіл. У структурі pKF48 є кодуюча послідовність уEGFP3 (yeast-enhanced Green Fluorescent Protein) під контролем промотора MET25, який позитивно регулюється за умов дефіциту метіоніну в ростовому середовищі. Ген SNCA був клонований у pKF48-SNCA за допомогою ендонуклеаз рестрикції Xhol, Clal (позначених на карті) так, що N-кінець $\alpha$-syn був злитий з GFP

$\boldsymbol{A}$

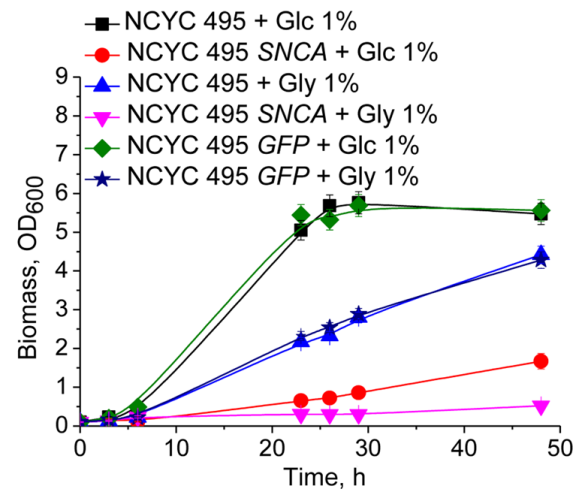

B

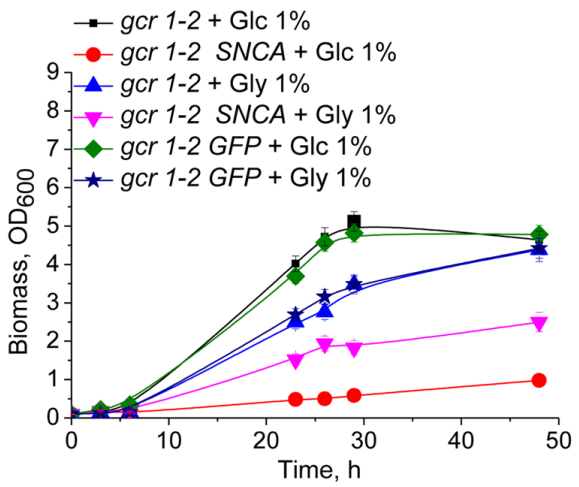

Fig. 3. Growth of $H$. polymorpha strains producing human a-syn (NCYC 495 SNCA and gcr 1-2 SNCA) cultivated in media with different carbon sources: $\boldsymbol{A}-$ NCYC495 SNCA on $1 \%$ glucose and $1 \%$ glycerol; B-gcr1-2 SNCA on $1 \%$ glucose and $1 \%$ glycerol

Рис. 3. Кінетика росту штамів Н. polymorpha, які продукують $\alpha$-syn людини (NCYC 495 SNCA igcr 1-2 SNCA), культивованих у середовищах із різними джерелами Карбону: $\boldsymbol{A}$ - NCYC495 SNCA (середовище з 1 \% глюкози та 1 \% гліцеролу); $\boldsymbol{B}$ - gcr1-2 SNCA (середовище з 1 \% глюкози та 1 \% гліцеролу)

Interestingly, whereas both $\alpha$-syn-expressing strains were similarly significantly affected in the growth on glucose, impairment of glycerol utilization was more pronounced for the wild-type NCYC495-SNCA relative to the mutant strain gcr1-2-SNCA. 
gcr1-2 mutation enhances human $\alpha$-syn aggregation in $\boldsymbol{H}$. polymorpha cells. Glucose (a glycolytic substrate) and glycerol (a gluconeogenic substrate) were used as alternative carbon sources to compare the possible effect of defective glucose transport/ metabolism proficiency on $\alpha$-syn aggregation. Fluorescent microscopy of the wild-type strain NCYC495-SNCA grown either in glucose- or glycerol-containing liquid medium revealed that there was only minor aggregate formation in cytoplasm of the cells (Fig. 4). We assumed therefore that $\alpha$-syn is accumulated in cytoplasm primarily in oligomeric forms. Fluorescent microscopy of gcr1-2-SNCA cells with defect in glucose utilization indicated significantly enhanced aggregation of fluorescently tagged $\alpha$-syn (Fig. 4). However, such amyloid-like aggreagtes were evidently formed in gcr1-2-SNCA cells in both glucose- and glycerol-containing media. Therefore, we concluded that polymerization of $\alpha$-syn in gcr1-2-SNCA is not a result of disturbances in glucose-dependent metabolism but rather of other pleiotropic effects of gcr1-2 mutation [25], which we will address in further studies. It has to be also further elucidated, how the rate $\alpha$-syn aggregation affects cells growth rate depending on the producer genetic background.

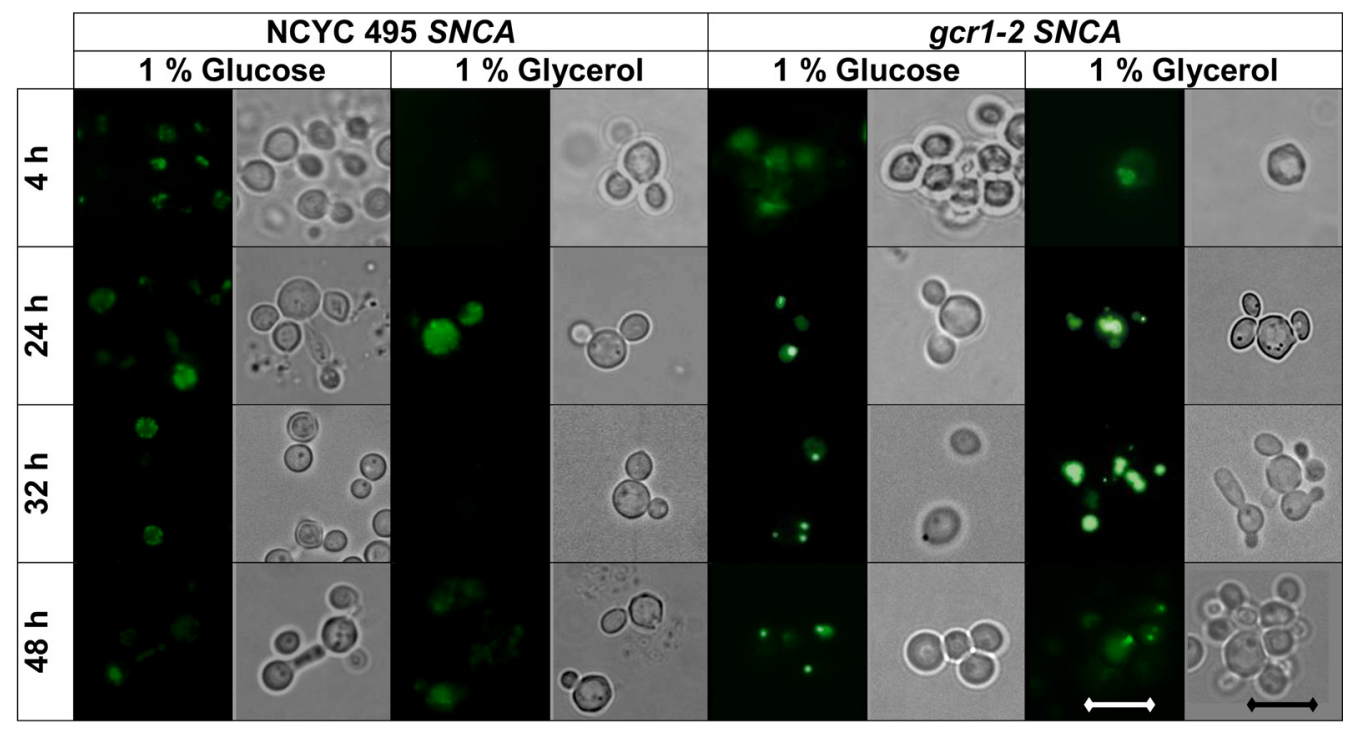

Fig. 4. Fluorescent microphotography of $H$. polymorpha strains NCYC 495 SNCA and gcr 1-2 SNCA producing human $\alpha$-syn (GFP-tagged) grown on media containing glucose $(1 \%)$ and glycerol $(1 \%)$ as carbon sources. The bar represents $5 \mu \mathrm{m}$ length

Рис. 4. Флюоресцентна мікроскопія штамів H. polymorpha NCYC 495 SNCA та gcr 1-2 SNCA, які продукують $\alpha$-syn (GFP-мічений), вирощених на середовищі з глюкозою (1\%) та гліцеролом (1\%) як джерелами Карбону. Відрізок на рисунку відповідає 5 мкм

Oligomers or small aggregates of $\alpha$-syn cause plasma membrane perforations and cytosol leakage in yeast cells. Remarkably, we also observed that glucosegrown NCYC495-SNCA cells apparently exhibited perforation of plasma membrane with further cytosol leakage after $24 \mathrm{~h}$ of cultivation (Fig. 5). Extracellular fluorescent $\alpha$-syn aggregates evidenced cytosol leakage out of yeast cells. Similar changes in the glycerol-grown cells of this strain were observed after $48 \mathrm{~h}$ of cultivation (data not shown). However, no such effect was observed for the mutant strain gcr1-2-SNCA.

ISSN 1996-4536 (print) • ISSN 2311-0783 (on-line) • Біологічні Студії / Studia Biologica • 2014 • Том 8/№2 • С. 5-16 

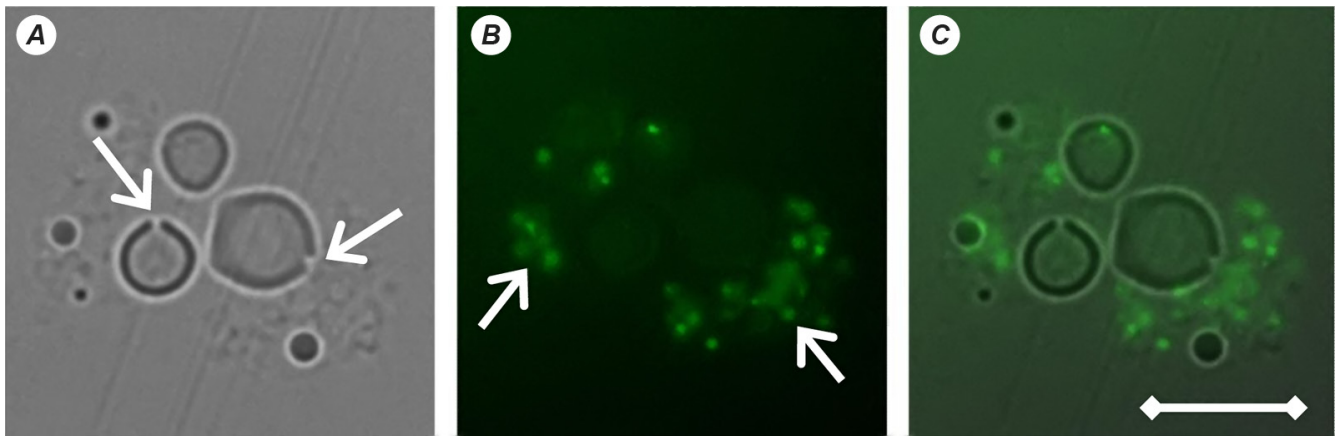

Fig. 5. $\boldsymbol{A}$ - Plasma membrane perforation in yeast cells producing $\alpha$-syn (NCYC495 SNCA), light microscopy. $\boldsymbol{B}$ - Cytosol outflow in the same cells, fluorescent microscopy. GFP-tagged $\alpha$-syn is glowing after excitation by ultraviolet light. $\mathbf{C}$ - merged images of light and fluorescent microscopy. The bar represents $5 \mu \mathrm{m}$ length

Рис. 5. $\boldsymbol{A}$-Перфрорації у плазматичній мембрані клітин дріжджів, які продукують $\alpha$-syn (NCYC495 SNCA); світлова мікроскопія. B - Витік цитозолю в тих самих клітин; фрлюоресцентна мікроскопія. GFPмічений $\alpha$-syn фрлюоресціює після збудження ультрафіолетовим світлом. $\boldsymbol{C}$ - накладання мікрофотографрій світлової та флюоресцентної мікроскопії. Відрізок на рисунку відповідає 5 мкм

Two mechanisms have been proposed to explain such effect of $\alpha$-syn oligomers on membrane permeability [31]: 1) $\alpha$-syn annular oligomers may integrate into the membrane resulting in the formation of pores or channel-like structures that could cause uncontrolled membrane permeability [14, 33], and 2) oligomers enhance the ability of ions to move through the membrane bilayer, without the formation of pores [12]. According to the Barrel model (Fig. 6) $\alpha$-syn oligomers ( $\beta$-sheet-rich) form circle structures with central pore. These aggregates can bind with the membrane causing its permeabilization in a concentration-dependent manner [19]. Thus we hypothesize that intercalation of $\alpha$-syn oligomers into cell membrane causes cell lysis in yeast strains that produce this heterologous protein.

Formation of large $\alpha$-syn aggregates (fibrils), as observed in the gcr1-2-SNCA mutant, apparently have cytoprotective effect and may prevent cell membrane perforation and cytosol leakage.

\section{CONCLUSIONS}

Modeling processes assosiated with human neurodegenerative diseases in yeasts has been already proven to be very useful to deciphering the complex mechanisms and pathways underlying these pathologies [9]. In this report we describe for the first time that methylotrophic yeast $H$. polymorpha can be an informative model for investigation of molecular mechanisms of PD. This yeast has several advantages, such as full genome sequencing, well developed platform for regulated heterologous protein production and its extreme thermotolerance [13]. The latter fact allows to study PD-related mechanisms at physiological for both human organism and this yeast temperature, $37^{\circ} \mathrm{C}$. H. polymorpha has also been extensively used as a model for studying autophagic protein degradation [16] known to be involved in protein aggregates clearance, like in the case of $\alpha$-syn amyloids.

In this study we have constructed $H$. polymorpha strains with normal and partially defective glucose transport/metabolism, gcr1-2 [25], wich heterologously produce human $\alpha$-syn in a regulated manner. We demonstrated that $\alpha$-syn expression dramatically affects physiology of the yeast cells, as is indicated by the decreased growth rate on 


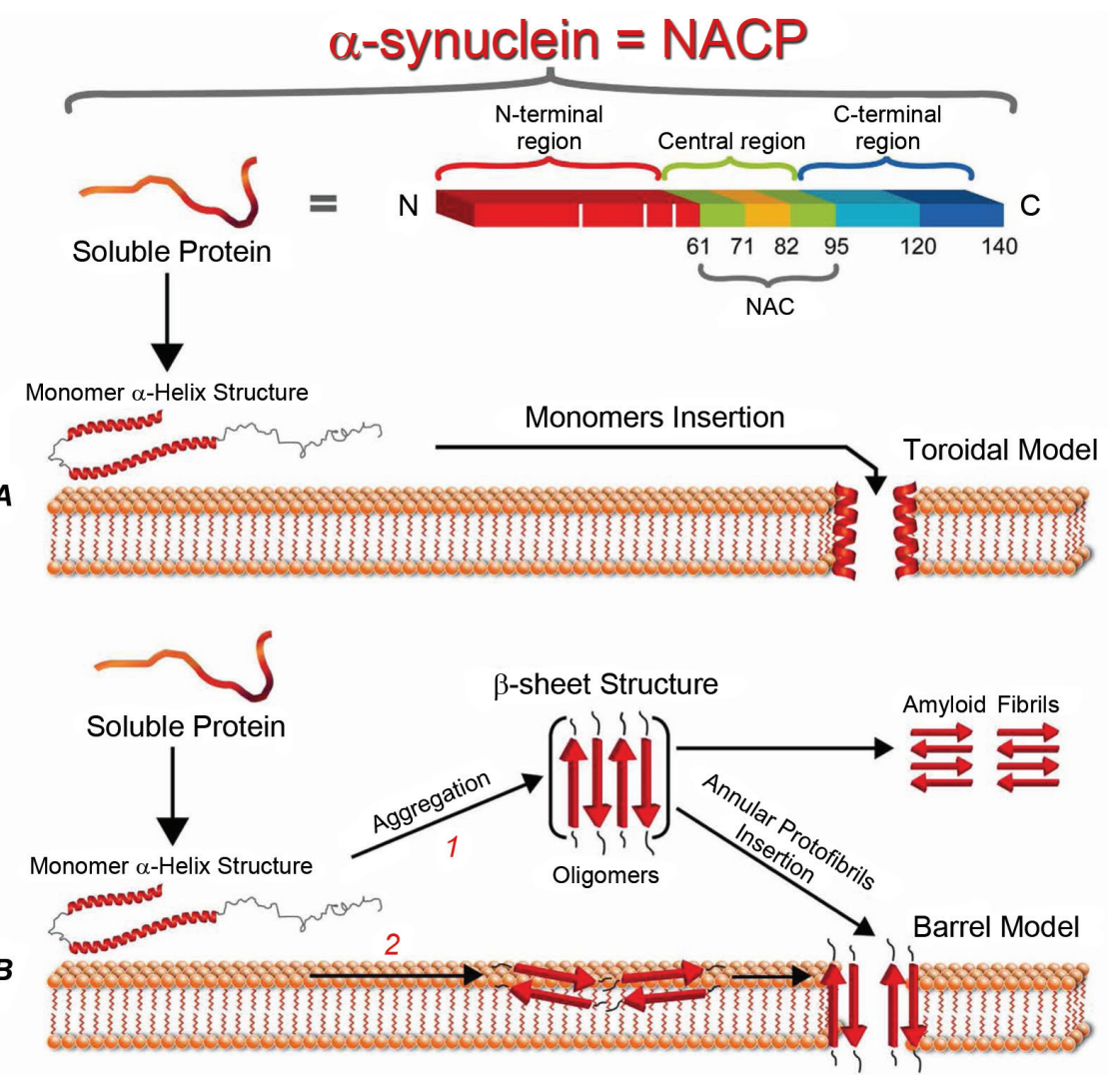

Fig. 6. Primary and secondary structure of $\alpha$-syn [19]. Top scheme shows the three main domains of $\alpha$-syn. The $\mathrm{N}$-terminal (red) is an amphipathic domain that contains the three point mutations (white bars) linked to the autosomal dominant form of PD. The central region (green-pale brown) is a highly hydrophobic domain that was originally identified in patients with $A D$ or LBD, which is the precursor of the nonamyloidogenic component of the extracellular senile plaque (NAC), which promotes the protein aggregation. The C-terminal domain (blue) has an acidic character, which possesses anti-amyloidogenic properties. According to the operational model of membrane perforation, once $\alpha$-syn interacts with the plasma membrane, it should acquire a new secondary structure to form pores/perforations. The formation of $\alpha$-syn pores may be explained by two different models: $(\boldsymbol{A}) \mathrm{A}$ toroidal model involving a sequential binding of $\alpha$-syn monomers to the plasma membrane that results in the formation of pores or channels with $\alpha$-helical conformation; and (B) A barrel model showing that $\alpha$-synuclein oligomers ( $\beta$-sheet-rich) form ring structures with a central pore. The formation of $\alpha$-syn oligomers enriched in $\beta$-sheet structures could occur in the extracellular space (1) or at the plasma membrane (2)

Рис. 6. Первинна і вторинна структура $\alpha$-syn [19]. На верхній схемі показані три основні домени $\alpha$-syn. $\mathrm{N}$-кінець (червоний) є амфіпатичним доменом, який містить три точкових мутації (білі стовпчики), пов'язані з аутосомно-домінантною формою ХБ. Центральна ділянка (зелено-світло-коричнева) $\epsilon$ сильно гідрофобним доменом, який спочатку був ідентифікований у пацієнтів з ХП або деменцією з тільцями Леві, який є попередником неамілоїдогенних компонентів позаклітинних бляшок, який сприяє агрегації білків. С-кінцевому домену (синій), збагаченому карбоксиамінокислотами, притаманні анти-амілоїдогенні властивості. Відповідно до діючої моделі мембранних перфорацій у разі взаємодії з плазматичною мембраною $\alpha$-syn набуває нової вторинної структури для утворення пор/перфорацій. Формування $\alpha$-syn пор можна пояснити двома різними моделями: $(\boldsymbol{A})$ модель тороїда, яка передбачає послідовне зв'язування $\alpha$-syn мономерів із плазматичною мембраною, що призводить до утворення пор або каналів з $\alpha$-спіральною конформацією; (B) модель бочки, згідно з якою $\alpha$-синуклеїнові олігомери (багаті на $\beta$-структурні ділянки) фоормують кільцеві структури з центральною порою. Формування $\alpha$-syn олігомерів, збагачених $\beta$-структурними ділянками, може відбутися у позаклітинному просторі (1) або на плазматичній мембрані (2) 
alternative carbon sources (Fig. 3). Remarkably, mutant strain with gcr1-2 mutation exhibited more efficient amyloid formation than corresponding wild-type strain, and no membrane perforations which are most probably caused by $\alpha$-syn oligomers (Fig. 4). However, these effects are not a direct function of the impaired glucose metabolism as were also observed in cells grown on a gluconeogenic substrate. The question of what molecular mechanisms evoked by gcr1 mutation stimulate $\alpha$-syn aggregation will be addressed in our prospective studies.

1. Aviles-Olmos I., Limousin P., Lees A., Foltynie T. Parkinson's disease, insulin resistance and novel agents of neuroprotection. Brain, 2012; 136(Pt 2): 374-84.

2. Baltic S., Perovic M., Mladenovic A. et al. $\alpha$-syn Is Expressed in Different Tissues During Human Fetal Development. Journal of Molecular Neuroscience, 2004; 22(3): 199-203.

3. Beyer K. Alpha-synuclein structure, posttranslational modification and alternative splicing as aggregation enhancers. Acta Neuropathol, 2006; 112(3): 237-51.

4. Bocer T., Zarubica A., Roussel A. The mammalian ABC transporter ABCA1 induces lipid-dependent drug sensitivity in yeast. Biochimica et Biophysica Acta (BBA), 2012; 1821(3): 373-380.

5. Bodner R.A., Outeiro T.F., Altmann S. et al. Pharmacological promotion of inclusion formation: A therapeutic approach for Huntington's and Parkinson's diseases. PNAS, 2004; 103(11): 4246-4251.

6. Chen L., Periquet M., Wang $X$. et al. Tyrosine and serine phosphorylation of $\alpha$-syn have opposing effects on neurotoxicity and soluble oligomer formation. J. Clin. Invest, 2009; 119: 3257-3265.

7. Emadi S., Barkhordarian H., Wang M. S. et al. Isolation of a human single chain antibody fragment against oligomeric $\alpha$-syn that inhibits aggregation and prevents $\alpha$-syn induced toxicity. J. Mol. Biol, 2007; 368(4): 1132-1144.

8. Faber K.N., Haima P., Harder W. et al. Highly-efficient electrotransformation of the yeast Hansenula polymorpha. Curr. Genet,1994; 25: 305-310.

9. Franssens V., Bynens T., Van den Brande J. et al. The benefits of humanized yeast models to study Parkinson's disease. Oxidative Medicine and Cellular Longevity (Hindawi Publishing Corporation), 2013; 2013: Article ID 760629, 9 pages. http://dx.doi.org/10.1155/2013/760629.

10. Gellissen G. Heterologous protein production in methylotrophic yeasts. Appl. Microbiol, 2000; Biotechnol. 54: 741-750.

11. Hashimoto M., Rockenstein E., Crews L., Masliah E. Role of protein aggregation in mitochondrial dysfunction and neurodegeneration in Alzheimer's and Parkinson's diseases. Neuro Molecular Medicine, 2003; 4: 21-35.

12. Kayed R., Sokolov Y., Edmonds B. et al. Permeabilization of lipid bilayers is a common conformation-dependent activity of soluble amyloid oligomers in protein misfolding diseases, $\mathbf{J}$. Biol. Chem, 2004; 279: 46363-46366.

13. Krasovska O.S., Stasyk O.G., Nahorny V.O. et al. Glucose-induced production of recombinant proteins in Hansenula polymorpha mutants deficient in catabolite repression. Biotechnol. Bioeng, 2007; 97: 858-870.

14. Lashuel H.A., Hartley D., Petre B.M. et al. Neurodegenerative disease: amyloid pores from pathogenic mutations. Nature, 2002; 418(6895): 291.

15. Lücking C.B., Brice A. Alpha-synuclein and Parkinson's disease. Cell. Mol. Life Sci, 2000; 57: 1894-1908.

16. Monastryska I., Sjollema K., Van-Der-Klei I. J. et al. Microautophagy and macropexophagy may occur simultaneously in Hansenula polymorpha. FEBS Letters, 2004; 568(1-3): 135-138.

17. Norris E.H., Giasson B. I., Lee V.M.-Y. Synuclein: normal function and role in neurodegenerative diseases. Curr Top Dev Biol, 2004; 60: 17-54.

18. Ocampo A., Barrientos A. Developing yeast models of human neurodegenerative disorders. Methods Mol Biol, 2011; 793: 113-27.

ISSN 1996-4536 (print) • ISSN 2311-0783 (on-line) • Біологічні Студії / Studia Biologica • 2014 • Том 8/№2 • C. 5-16 
19. Pacheco C., Aguayo L.G., Opazo C. An extracellular mechanism that can explain the neurotoxic effects of $\alpha$-syn aggregates in the brain. Front. Physiol, 2012; 3: 297.

20. Pieri L., Madiona K., Bousset L., Melki, R. Fibrillar alpha-synuclein and huntingtin exon 1 assemblies are toxic to the cells. Biophys. J, 2012; 102: 2894-2905.

21. Ross C.A., Poirier M.A. Protein aggregation and neurodegenerative disease. Nat. Med, 2004; 10: S10-S17.

22. Sambrook J., Russel D. Molecular cloning: a laboratory manual. $3^{\text {rd }}$ ed. Cold Spring Harbor Laboratory, 2001. 3 vol.: 510 p.

23. Sandyk $R$. The relationship between diabetes mellitus and Parkinson's disease. Intern. J. Neuroscience, 1993; 69: 125-130.

24. Santangelo G. Glucose signaling in Saccharomyces cerevisiae. Microbiol. Mol. Biol. Rev, 2006; 70(1): 253-258.

25. Stasyk O.V., Stasyk O.G., Komduur J. et al. A hexose transporter homologue controls glucose repression in the methylotrophic yeast Hansenula polymorpha. J. Biol. Chem, 2004; 279(9): 8116-25.

26. Sun Y., Chang Y.-H., Chen H.-F. et al. Risk of Parkinson Disease Onset in Patients With Diabetes. Diabetes Care, 2012; 35(5): 1047-1049.

27. Tenreiro S., Outeiro T.F. Simple is good: yeast models of neurodegeneration. FEMS Yeast Res, 2010; 10: 970-979.

28. Uéda K., Saitoh T., Mori H. Tissue-dependent alternative splicing of mRNA for NACP, the precursor of non-A beta component of Alzheimer's disease amyloid. Biochem. Biophys. Res. Commun, 1994; 205(2): 1366-72.

29. Vekrellis K., Xilouri M., Emmanouilidou E. et al. Pathological roles of $\alpha$-syn in neurological disorders. Lancet Neurol, 2011; 10(11): 1015-25

30. Volles M.J., Lee S.-J., Rochet J.-C. et al. Vesicle permeabilization by protofibrillar $\alpha$-syn: implications for the pathogenesis and treatment of Parkinson's disease. Biochemistry, 2001; 40: 7812-7819.

31. Waxman E. A., Giasson B. I. Molecular mechanisms of $\alpha$-syn neurodegeneration. Biochimica et Biophysica Acta (BBA), 2009; 1792: 616-624.

32. Xu Q., Park Y., Huang X. et al. Diabetes and risk of Parkinson's disease. Diabetes Care, 2011; 34: 910-815.

33. Zakharov S.D., Hulleman J.D., Dutseva E A. et al. Helical alpha-synuclein forms highly conductive ion channels. Biochemistry, 2007; 46: 14369-14379.

\title{
МОДЕЛЮВАННЯ МОЛЕКУЛЯРНИХ ПРОЦЕСІВ, ЯКІ ПРИЗВОДЯТЬ ДО ХВОРОБИ ПАРКІНСОНА, В КЛІТИНАХ МЕТИЛОТРОФНИХ ДРІЖДЖІВ HANSENULA POLYMORPHA
}

\author{
І. О. Денега, ${ }^{1,2}$, Н. І. Климишин², Н. О. Сибірна², О. В. Стасик', О. Г. Стасик', 2 \\ 1 /нститут біології клітини НАН України, вул. Драгоманова, 14/16, Львів 79005, Україна \\ ${ }^{2}$ Львівський національний університет імені Івана Франка \\ вул. Грушевського, 4, Львів 79005, Україна \\ e-mail: olenastasyk@gmail.com
}

Аномальна олігомеризація і агрегація білка, який називається альфа-синуклеїн ( $\alpha$-syn), є ключовими подіями в патогенезі ХП. Останні дослідження виявили зв'язок Н3 з аномальним функціонуванням мітохондрій і дефектним метаболізмом глюкози. У цій статті ми вперше описуємо штами термотолерантних метилотрофних дріжджів Hansenula polymorpha, що продукують GFP-мічений людський $\alpha$-syn і можуть слугувати моделлю ХП. Нами було виявлено, що штам дикого типу NCYC495-SNCA не фрормував видимих амілоїдів $\alpha$-syn, проте характеризувався наявністю перфорацій у цитоплазматичній мембрані та витіканням цитозолю. Мутантному штаму

ISSN 1996-4536 (print) • ISSN 2311-0783 (on-line) • Біологічні Студії / Studia Biologica • 2014 • Том 8/№2 • С. 5-16 
gcr1-2-SNCA, який має пошкоджену катаболітну репресію та глюкозний транспорт, була притаманна посилена агрегація флюоресцентно міченого $\alpha$-syn. Однак така відмінність у здатності утворювати агрегати не була результатом пошкодження метаболізму глюкози, оскільки також спостерігалась і у разі вирощування клітин на середовищі з гліцеролом. Продукція $\alpha$-syn була шкідливою для обох штамів і пригнічувала їхній ріст на альтернативних карбонових субстратах. Отримані нами дані свідчать про те, що Н. polymorpha може слугувати новою інформативною дріжджовою моделлю для з'ясування молекулярних механізмів ХП, які регулюють фрормування та деградацію амілоїдів під впливом різноманітних поза- та внутрішньоклітинних фракторів.

Ключові слова: метилотрофні дріжджі, $\alpha$-синуклеїн, амілоїди, нейродегенерація.

\title{
МОДЕЛИРОВАНИЕ МОЛЕКУЛЯРНЫХ ПРОЦЕССОВ, ЛЕЖАЩИХ В ОСНОВЕ БОЛЕЗНИ ПАРКИНСОНА, В КЛЕТКАХ МЕТИЛОТРОФНЫХ ДРОЖЖЕЙ HANSENULA POLYMORPHA
}

\author{
И. О. Денега",, Н. И. Клымышин², Н. О. Сибирная², О. В. Стасык', О. Г. Стасык', \\ ${ }^{1}$ Институт биологии клетки НАН Украины, ул. Драгоманова, 14-16, Львов 79005, Украина \\ ${ }^{2}$ Львовский национальный университет имени Ивана Франко \\ ул. Грушевского, 4, Львов 79005, Украина \\ e-mail: olenastasyk@gmail.com
}

Аномальная олигомеризация и агрегация белка, который называется альфасинуклеин ( $\alpha$-syn), являются ключевыми событиями в патогенезе болезни Паркинсона (БП). Последние исследования обнаружили связь нейродегенеративных заболеваний (H3) с аномальным функционированием митохондрий и дефектным метаболизмом глюкозы. В этой статье мы впервые описываем штаммы термотолерантных метилотрофных дрожжей Hansenula polymorpha, продуцирующие GFPмеченый человеческий $\alpha$-syn, которые могут служить моделью БП. Нами было обнаружено, что штамм дикого типа NCYC495-SNCA не формировал видимых амилоидов $\alpha$-syn, однако характеризовался наличием перфораций в цитоплазматической мембране и вытеканием цитозоля. Мутантному штамму gcr1-2-SNCA, имеющему поврежденную катаболитную репрессию и глюкозный транспорт, была присуща усиленная агрегация флюоресцентно меченого a-syn . Однако такое различие в способности образовывать агрегаты не является результатом повреждения метаболизма глюкозы, поскольку также наблюдалось и в случае выращивания клеток в среде с глицеролом. Продукция $\alpha$-syn была вредной для обоих штаммов и подавляла их рост на альтернативных карбоновых субстратах. Полученные нами данные свидетельствуют о том, что $H$. polymorpha может служить новой информативной дрожжевой моделью процессов, лежащих в основе БП, для выяснения молекулярных механизмов, которые регулируют фрормирование и деградацию амилоидов под влиянием различных вне- и внутриклеточных фракторов.

Ключевые слова: метилотрофные дрожжи, $\alpha$-синуклеин, амилоиды, нейродегенерация.

Одержано: 06.02.2014

ISSN 1996-4536 (print) • ISSN 2311-0783 (on-line) • Біологічні Студії / Studia Biologica • 2014 • Том 8/№2 • C. 5-16 